\title{
Analisis Ketersediaan Air Menggunakan Model Rain Run NRECA dan Tangki di DAS Babak
}

\author{
Analysis of Water Availability Uses the NRECA And Tank Model in The Babak \\ Watershed
}

\author{
Ida Bagus Subrata ${ }^{1 *)}, \operatorname{Hartana}^{1}$, Ery Setiawan ${ }^{1}$ \\ ${ }^{1}$ Jurusan Magister Teknik Sipil, Fakultas Teknik, Universitas Mataram, Mataram, Indonesia.
}

\section{Article info:}

Kata kunci:

AWLR, Babak, bendung, Keru, NRECA, Tangki

Keywords:

AWLR, Babak, Keru, NRECA, tank, weir

\section{Article history:}

Received: 22-10-2020

Accepted: 27-11-2020

${ }^{*}$ Koresponden email: ibas.nt1.2018@gmail.com

\begin{abstract}
Abstrak
Dalam penelitian ini akan ditinjau pemodelan NRECA maupun Tangki pada Bendung Keru di DAS Babak yang memiliki ketersedian catatan debit air. Pemodelan dimulai dari kalibrasi model rain run sehingga mendapatkan koefisien NRECA dan Tangki pada AWLR Keru. Kemudian perhitungan debit pada Bendung Keru menggunakan data spasial serta data curah hujan dari ARR Keru. Hasil antara pemodelan pada NRECA dan Tangki dibandingkan dengan catatan debit pada Bendung Keru. Hasil dari penelitian ini adalah nilai koefisien model pada AWLR Keru di DAS Babak WS Lombok: a) Koefisien model NRECA yaitu untuk tampungan kelengasan awal : 727; tampungan kelengasan akhir: 312; koefisien reduksi: 0.27; koefisien PSUB: 0.43; koefisien GWF: 0.1; beda tampungan awal dan akhir: 12; nilai korelasi: 0.84; nilai volume error (VE): 0.33; b) Koefisien model Tangki yaitu koefisien Tangki 1: tank awal : 868; H 1.1 : 29; H 1.2 : 28; F 1.1 : 794; F 1.2 : 661; B1: 254; koefisien Tangki 2: tank awal : 330; B2 : 585; nilai korelasi : 0.75; nilai volume error (VE): 0.31. Dalam pemodelan debit untuk perhitungan ketersediaan air yang optimal di DAS Babak WS Lombok terutama pada Bendung Keru menggunakan model Tangki.
\end{abstract}

\begin{abstract}
In this research, the modeling of NRECA and Tank in Keru Weirs in the Babak watershed which have water discharge records available will be reviewed. Modeling starts from the calibration of rain run model so that NRECA and Tank coefficients are obtained on AWLR Keru. Then the calculation of discharge at Keru Weir uses spatial data and rainfall data from ARR Keru. Results between modeling at NRECA and Tank were compared with discharge records at Keru Weir. The results of this study are model coefficient values on AWLR Keru in the Babak WS Lombok watershed: a) The coefficient of NRECA model is for initial moisture reservoir: 727; final moisture storage: 312 ; reduction coefficient: 0.27 ; PSUB coefficient: 0.43 ; GWF coefficient: 0.1 ; the difference between the beginning and the end: 12 ; correlation value: 0.84 ; value volume error (VE): 0.33 ; b) The Tank model coefficient, namely tank coefficient 1 : initial tank: 868; H 1.1: 29; H 1.2: 28; F 1.1: 794; F 1.2: 661; B1: 254; tank coefficient 2: initial tank: 330; B2: 585; correlation value: 0.75 ; value volume error (VE): 0.31 . In the discharge modeling to calculate optimal water availability in the Babak WS Lombok watershed, especially in the Keru Dam, uses Tank model.
\end{abstract}




\section{Pendahuluan}

Dalam pemanfaatannya sumber daya air sebagai pemenuhan kebutuhan hidup manusia, dapat dilakukan melalui pembangunan bangunan air. Bangunan air tersebut dapat berupa bendung, bendungan maupun embung. Pengelolaan sumber daya air dengan pembangunan bangunan air merupakan alternatif dalam pemanfaatan air secara optimal.

Dalam melakukan perencanaan bangunan air diperlukan perencanaan awal yaitu melalui tahap analisis hidrologi. Analisis hidrologi dapat dilakukan secara langsung melalui pengukuran di penampang sungai menggunakan current meter maupun menggunakan alat baca tinggi muka air Automatic Water Level Recorder (AWLR) yang dikonversikan ke debit. Akan tetapi keterbatasan stasiun AWLR maupun pengukuran langsung yang membutuhkan waktu minimal dua kali musim menyebabkan sulitnya mendapatkan data. Sehingga pemodelan adalah alternatif dalam penyediaan data debit air dalam hal perencanaan (Akrom 2018).

Pemodelan menggunakan kalibrasi AWLR yang terdapat pada daerah aliran sungai (DAS) yang sama, dan memiliki sifat fisik dan keadaan hidrologi yang sama. Debit sangat mempengaruhi kerusakan DAS tersebut dengan menganalisis nilai $C$ dan KRS nya, sehingga pemodelan debit berpengaruh terhadap keberlanjutan DAS (Noviadi and Rizki 2020).

Wilayah sungai (WS) Lombok adalah salah satu wilayah sungai strategis Nasional yang terdiri dari 197 DAS di mana telah dibangun infrastruktur sumber daya air berupa bendung, embung maupun bendungan pada 52 DAS (Kementerian Pekerjaan Umum dan Perumahan Rakyat 2015). Pada 52 DAS terdapat 12 DAS yang saling terkoneksi satu sama lain melalui saluran high level diversion (HLD) yang berfungsi mengalirkan air di DAS yang memiliki sungai perenial ke DAS yang memiliki tipe sungai ephemeral maupun intermiten.

DAS Babak merupakan salah satu DAS yang memiliki tipe sungai perenial, sehingga perencanaan baik pembangunan bangunan air baru maupun operasional sangat berpengaruh pada DAS ini. Beberapa metode yang umum digunakan dalam pemodelan hidrologi adalah model Mock, NRECA maupun Tangki. Dalam penelitian ini akan dilakukan kajian pemodelan hidrologi model NRECA maupun Tangki pada DAS Babak yang memiliki catatan debit sehingga dapat diketahui pemodelan yang tepat digunakan untuk DAS Babak WS Lombok. Kemudian bendung yang dijadikan penelitian adalah Bendung Keru. Bendung Keru dipilih karena catatan debit yang memadai. Penelitian ini bertujuan mengetahui Model mana yang cocok untuk digunakan sebagai pemodelan dalam perhitungan debit di DAS Babak WS Lombok dengan sampel pada Bendung Keru.

\section{Bahan dan Metode}

Beberapa studi terdahulu terkait pemodelan hidrologi yang dilakukan menggunakan model Mock, NRECA dan Tangki. Seperti halnya dalam penelitian tentang model Mock, NRECA dan Tangki pada Bendung Trani, Wonotoro, Sundangan dan Walikan mendapat hasil terbaik yaitu pada pemodelan menggunakan model Tangki di mana hasil debit pada Bendung Trani yaitu koefisien korelasi adalah 0.625 , selisih volume sebesar $20 \%$; dan koefisien efisiensi sebesar $0.664 \%$, sedangkan pada Bendung Wonotoro mendapatkan hasil berupa $\mathrm{R}=0.462 ; \mathrm{VE}=20 \%$; dan $\mathrm{CE}=$ $0.661 \%$ (Kesuma, Wahyudi, and Suyanto 2013).

Penelitian tentang memperkirakan penyimpangan debit menggunakan model Mock dan NRECA mendapatkan hasil yaitu penyimpangan rata-rata kedua model yaitu $70.25 \%$ dan $85.93 \%$ dengan parameter sembarang. Sedangkan simulasi untuk mendapatkan parameter optimal, dengan menurunkan penyimpangan rerata menjadi $15.88 \%$ dan $23.97 \%$. Di mana didapatkan volume error sebesar 0.00056 dan 0.000724 dan koefisien korelasi sebesar 0.875 dan 0.824 (Tunas and Lesmana 2011).

Selanjutnya penelitian tentang mengoptimasi model Mock yang dilakukan pada DAS Lematang-Lebak budi didapatkan hasil parameter berupa koefisien korelasi sebesar 0.98 di mana volume error sebesar $2.52 \%$ sedangkan hasil validasi didapatkan nilai korelasi sebesar 0.75 dan volume error sebesar $2.03 \%$. Sehingga disimpulkan bahwa tingkat keandalan tinggi sehingga nilai $\mathrm{R}$ mendekati 1 dan volume error sebesar 0-5\% (Dinata 2018).

Pada penelitian tentang model Tangki terhadap konservasi serta hubungan terhadap debit sungai pada Sub DAS Ciliwung Hulu mendapatkan hasil kerusakan DAS diakibatkan perubahan tata guna lahan di hulu di mana kondisi termasuk kategori buruk dengan nilai (KRS) 132.72, dan 
berdasarkan simulasi model Tangki mendapatkan hasil $\mathrm{R}^{2}=0.822$ (Hendriyanto, Purwanto, and Setiawan 2019).

Penelitian tentang optimasi pemodelan hidrologi menggunakan Mock pada daerah tangkapan air waduk sempor mendapatkan hasil simulasi di mana luas tangkapan air waduk $44,158 \mathrm{~km}^{2}$, dan koefisien infiltrasi pada musim hujan sebesar 0.25 , koefisien infiltrasi musim kemarau sebesar 0.4, kelembaban tanah awal sebesar $100 \mathrm{~mm}$, kapasitas kelembaban tanah sebesar $150 \mathrm{~mm}$, penyimpanan air tanah awal sebesar $500 \mathrm{~mm}$ dan konstanta resesi air tanah 0.995 (Julia 2014).

Pada penelitian tentang perbandingan debit andalan hasil model Tangki terhadap debit pengamatan Sungai Tapung kiri stasiun Tandun mendapatkan hasil model Tangki dengan nilai RMSE kondisi musim basah $\left(\mathrm{Q}_{20 \%}\right)=6.70$; kondisi normal $\left(\mathrm{Q}_{50 \%}\right)=4.49$ dan musim kering $\left(\mathrm{Q}_{80 \%}\right)$ $=5.27$. Sehingga disimpulkan bahwa model Tangki yang digunakan dalam penelitian ini memiliki kinerja baik (Fachrunnisa, Manyuk, and Trimaijon 2019).

\subsection{Pemodelan NRECA}

Perhitungan ketersediaan air berfungsi agar mengetahui jumlah air yang ada dan tersedia untuk memenuhi kebutuhan (Kementerian Pekerjaan Umum 2003). Salah satu metode pendekatan yang dapat digunakan untuk menghitung ketersediaan air adalah metode NRECA. Dalam analisis menggunakan model NRECA harus ditetapkan terlebih dahulu AWLR yang akan dikalibrasi. Kalibrasi dilakukan dengan menetapkan nilai kesalahan tertentu, di mana nilai ini menjadi batasan error dalam penentuan koefisien. Koefisien NRECA yang diperoleh melalui kalibrasi, diterapkan pada setiap bangunan utama (BU) untuk mendapat nilai ketersediaan air antar bangunan utama (BU) (local inflow) dengan masukan (input) data berupa hujan data seri, luas CA bangunan utama (BU) serta evapotranspirasi potensial.

Cara perhitungan NRECA sesuai untuk daerah cekungan air tanah yang setelah hujan berhenti masih ada aliran air di sungai selama beberapa hari. Keadaan ini sering terjadi bila tangkapan air hujan cukup luas. Berikut skema simulasi debit model NRECA.

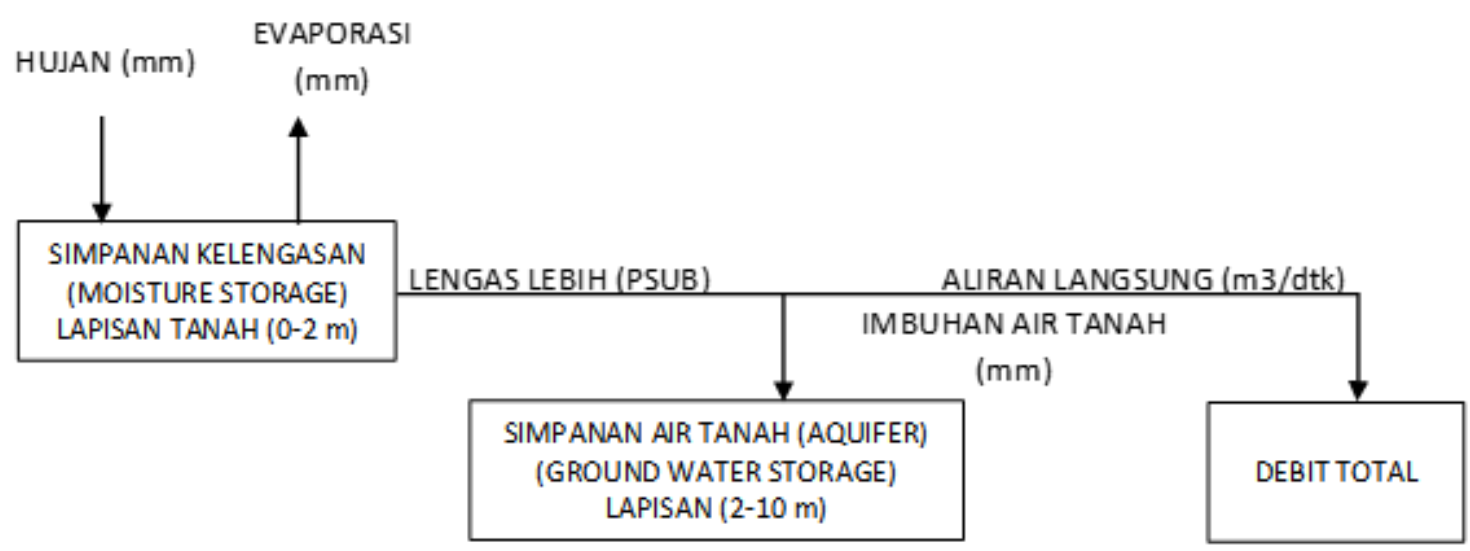

Gambar 1. Skema simulasi debit metode NRECA

\subsection{Pemodelan Tangki}

Model Tangki diperkenalkan oleh Sugawara yang merupakan simulasi dari sebuah DAS dengan mengubah tampungan menjadi Tangki. Tangki memiliki lubang pada dinding dan dasar. Aliran yang melewati lubang-lubang yang berada di dinding dianggap sebagai limpasan, sedangkan aliran yang mengarah kebawah merupakan infiltrasi (Kesuma, Wahyudi, and Suyanto 2013). Secara global persamaan keseimbangan air model Tangki adalah sebagai berikut (Setiawan 2003):

$$
\frac{\Delta H}{\Delta t}=P(t)-E T(t)-Y(t)
$$

dengan $\mathrm{H}$ merupakan tinggi air $(\mathrm{mm}), \mathrm{P}(\mathrm{t})$ merupakan hujan $(\mathrm{mm} / \mathrm{bulan})$, ET(t) merupakan evapotranspirasi $(\mathrm{mm} / \mathrm{bulan}), \mathrm{Y}(\mathrm{t})$ merupakan aliran total $(\mathrm{mm} / \mathrm{bulan})$, dan $\mathrm{t}$ merupakan waktu 
(bulan). Konsep pemodelan Tangki Sugawara, dapat diilustrasikan dengan menunjukkan proses di alam yang digambarkan dalam susunan Tangki (Gambar 2).

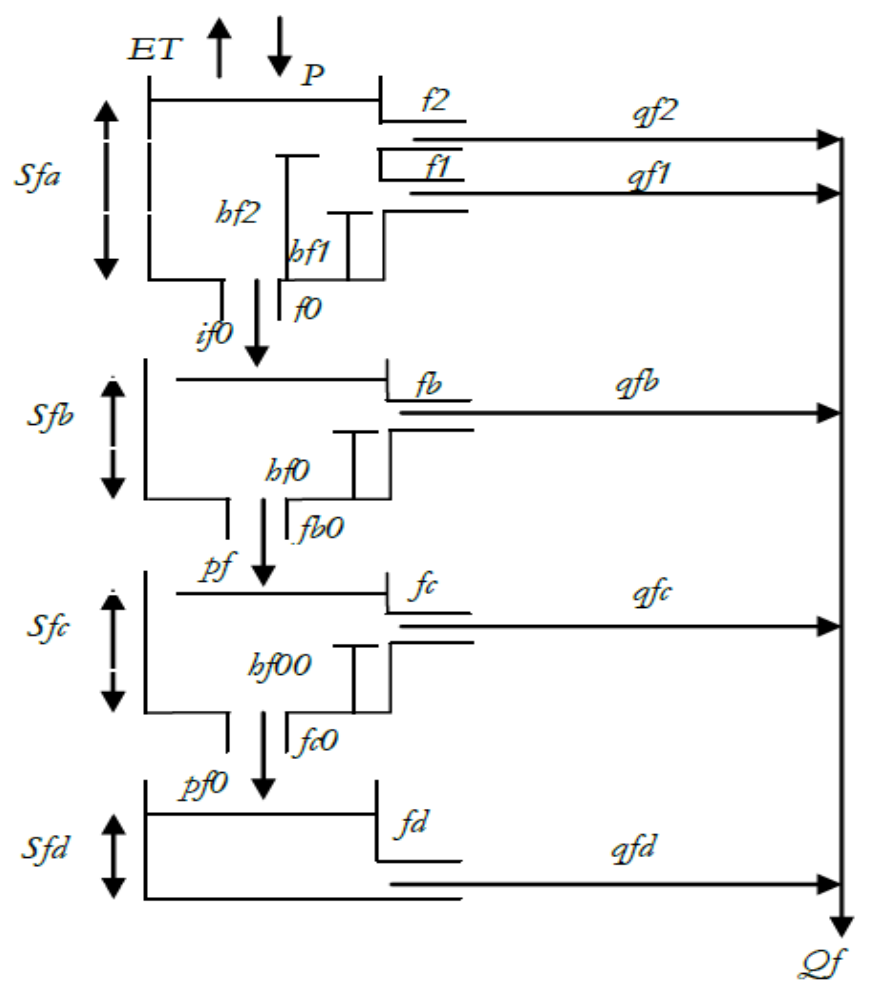

Gambar 2. Ilustrasi model Tangki

Sementara itu, debit andalan (dependable flow) adalah besarnya debit yang tersedia di catchment area pada sumber air untuk dapat dimanfaatkan dalam penyediaan air dengan risiko kegagalan yang telah diperhitungkan. Pengelolaan sumber daya air harus memperhatikan potensi sumber daya air yang ada. Potensi sumber daya air dalam konsep pengelolaan dibatasi oleh sistem alami yang dikenal sebagai wilayah sungai. Prediksi ketersediaan air di wilayah sungai sangat penting untuk pengelolaan air (Fauzi et al. 2019).

Ketersediaan air dinyatakan dalam debit andalan (dependable flow) atau debit minimum sungai yang terpenuhi 20\% (kondisi musim basah, $\mathrm{Q}_{20 \%}$ ), 50\% (kondisi normal, $\mathrm{Q}_{50 \%}$ ), dan $80 \%$ (kondisi musim kering, $\mathrm{Q}_{80 \%}$ ) dan dihitung dengan metode Weibull:

$$
P=\left[\frac{m}{n+1}\right] x 100 \%
$$

Di mana $\mathrm{P}$ merupakan probabilitas terjadinya kumpulan nilai (debit) yang diharapkan (\%), $\mathrm{m}$ merupakan nomor urut kejadian, dengan urutan variasi dari besar ke kecil dan $\mathrm{n}$ merupakan jumlah data debit pengamatan.

\section{Hasil dan Pembahasan}

Lokasi studi untuk pemodelan rain run/kalibrasi AWLR adalah pada AWLR Keru memiliki luas catchment area (CA) $23.92 \mathrm{~km}^{2}$ yang terletak pada koordinat $8^{\circ} 33^{\prime} 41^{\prime \prime}$ LS dan $116^{\circ} 15^{\prime} 28^{\prime \prime}$ serta Berlokasi di Desa Peresak, Kecamatan Narmada, Kabupaten Lombok Barat, Provinsi Nusa Tenggara Barat. Sedangkan lokasi studi perhitungan debit ketersediaan air yang digunakan sebagai validasi yaitu Bendung Keru di DAS Babak WS Lombok. Bendung Keru terletak pada koordinat 8 34'25.98” LS dan $116^{\circ} 15^{\prime} 55.56^{\prime}$ yang merupakan bendung suplesi dan berlokasi di Desa Sedau, Kecamatan Narmada, Kabupaten Lombok Barat, Provinsi Nusa Tenggara Barat. Berikut Peta DAS Babak WS Lombok (Balai Wilayah Sungai 2019). 


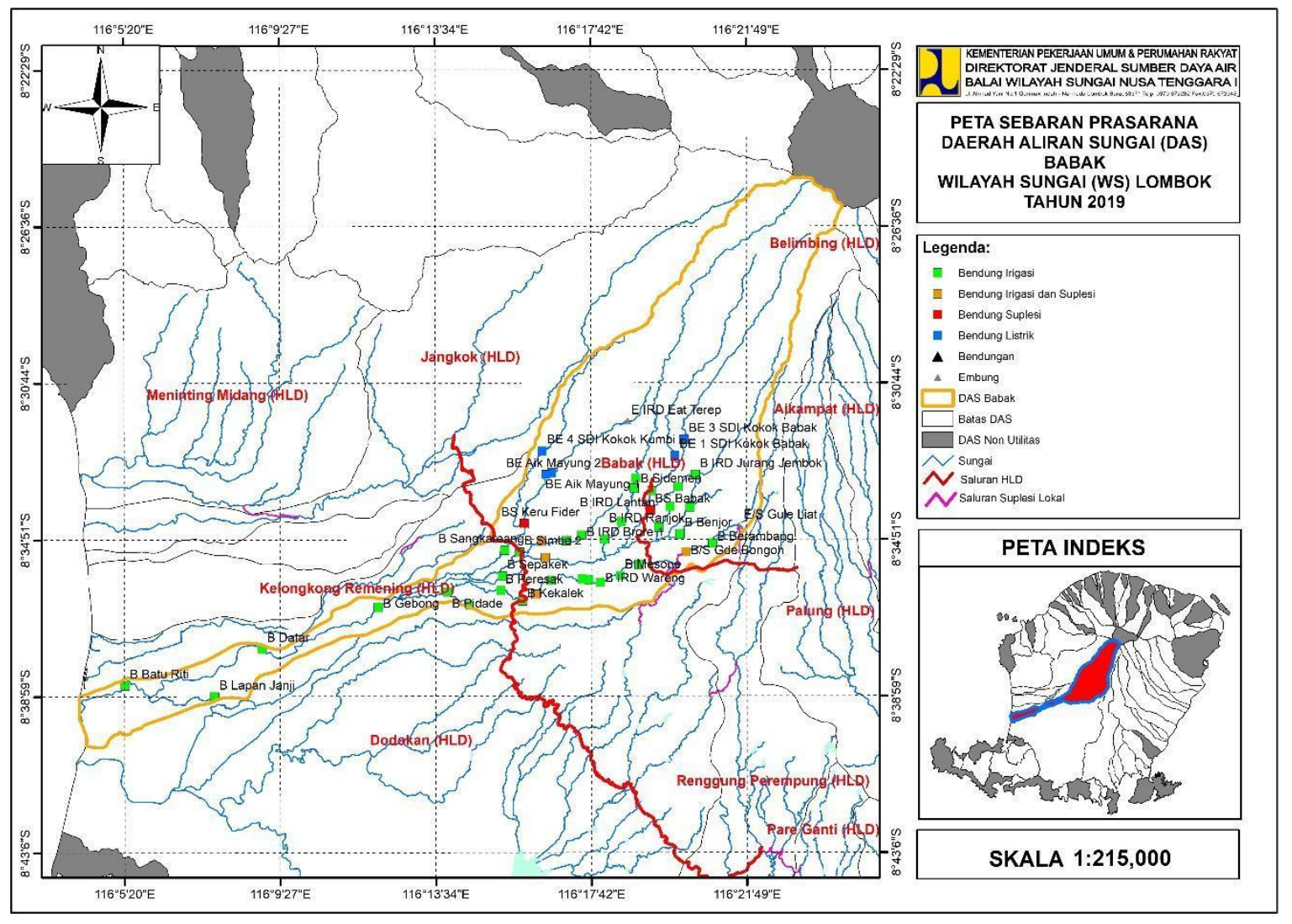

Gambar 3. Peta DAS Babak WS Lombok (Balai Wilayah Sungai 2019)

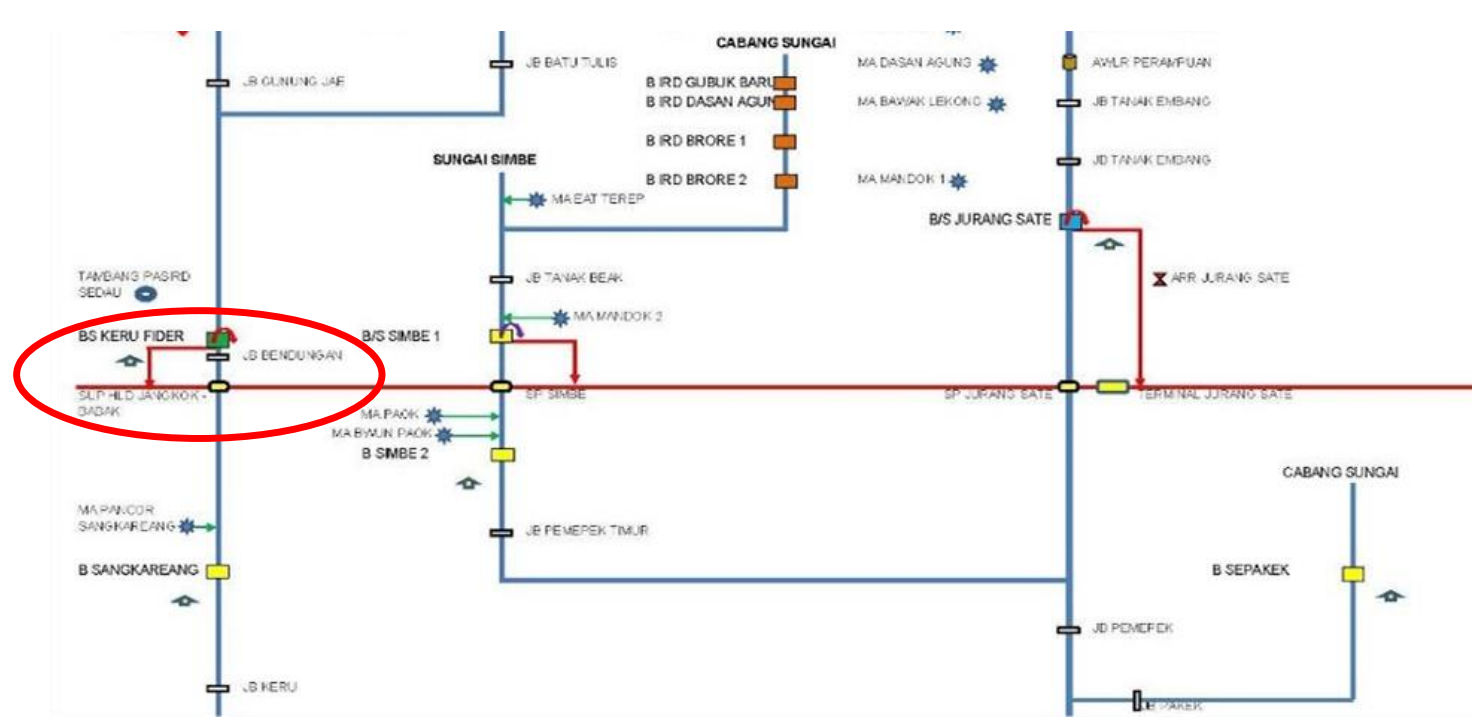

Gambar 4. Lokasi Bendung Sangkareang di DAS Babak WS Lombok (Balai Wilayah Sungai 2019) 

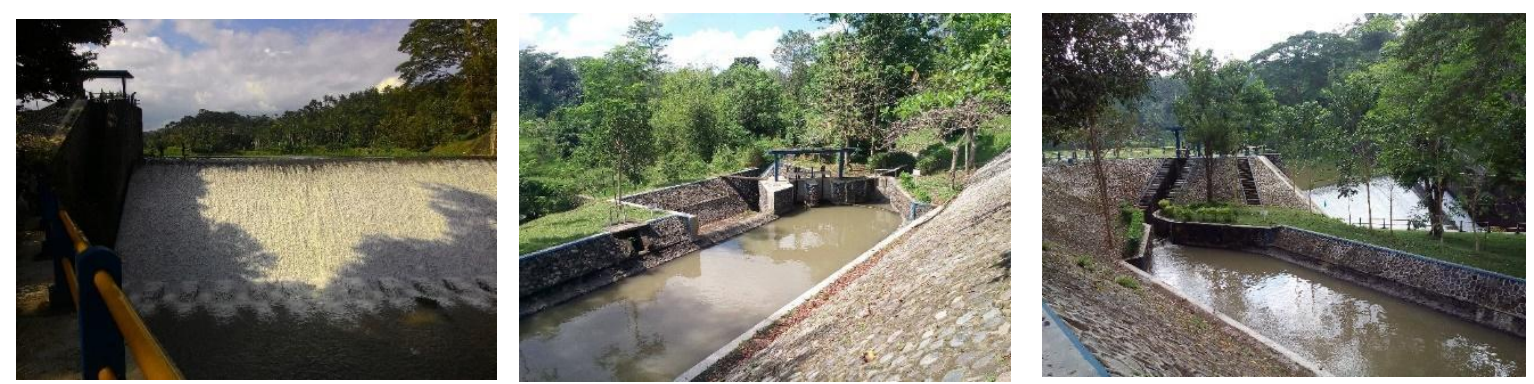

Gambar 5. Dokumentasi Bendung Keru DAS Babak WS Lombok (Balai Wilayah Sungai 2019)

\subsection{Data Hujan Wilayah}

Data curah hujan wilayah didapatkan dari data curah hujan rerata 10 tahun dari tahun 20082017. Data curah hujan yang digunakan didapat dari data curah hujan hasil Isohyet pada stasiun ARR yang berada di wilayah sungai Lombok. Berikut data curah hujan wilayah rerata 10 tahun hasil Isohyet di cacthment area AWLR Keru di DAS Babak WS Lombok.

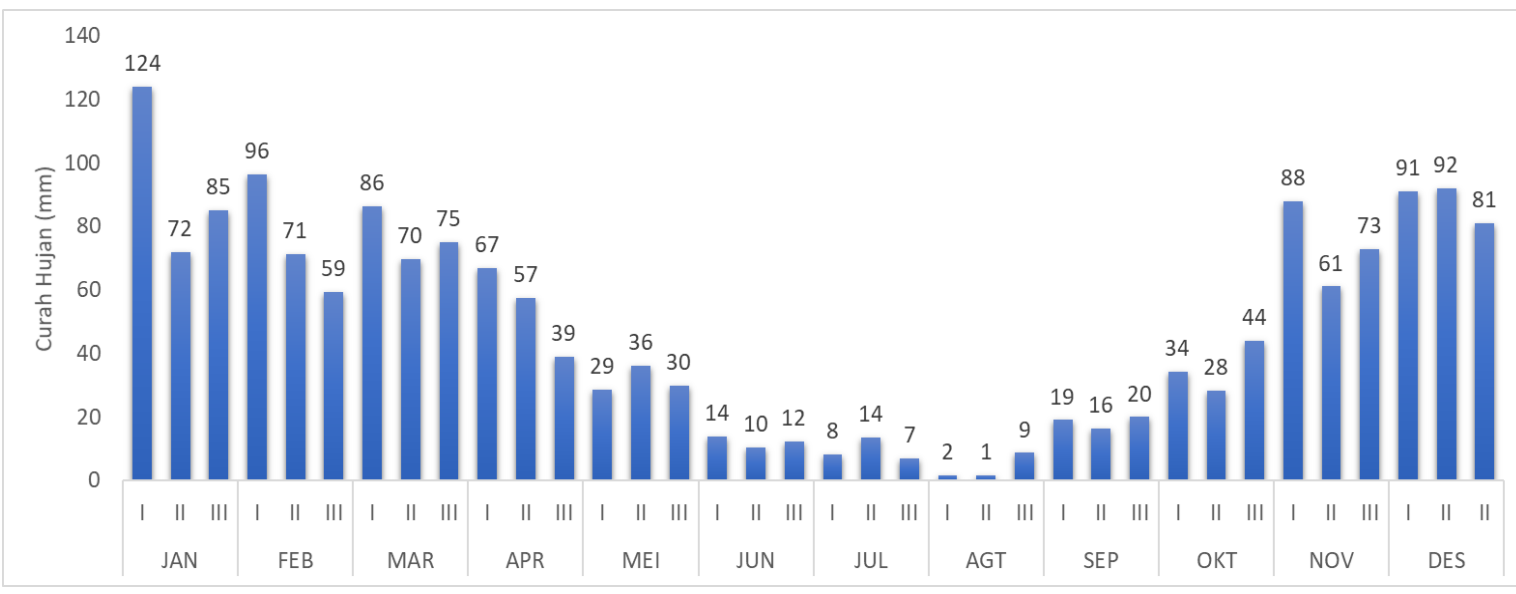

Gambar 6. Data curah hujan hasil Isohyet di catchment area AWLR Keru di DAS Babak WS Lombok

\subsection{Data Evaporasi Wilayah}

Data evaporasi wilayah yang digunakan adalah data evaporasi rerata 10 tahun dari tahun 20082017. Data evaporasi yang digunakan didapat dari data evaporasi hasil Isohyet pada stasiun CR yang berada di Wilayah Sungai Lombok. Berikut data evaporasi wilayah rerata 10 tahun hasil di cacthment area AWLR Keru di DAS Babak WS Lombok.

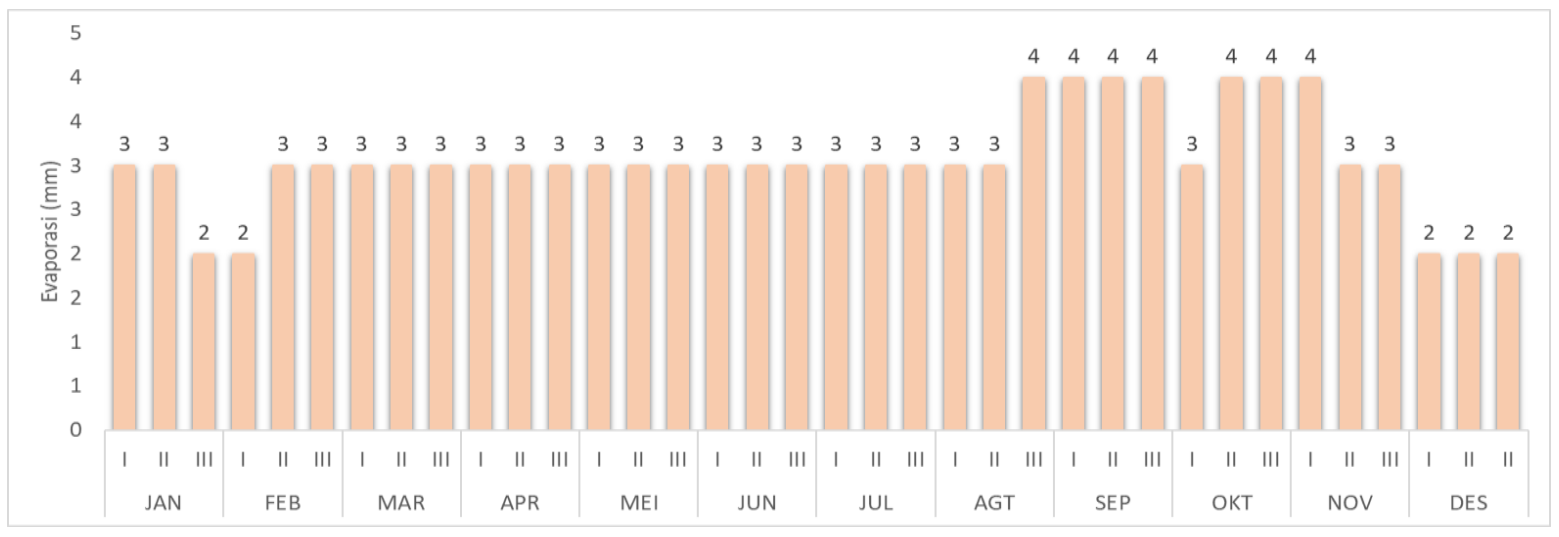

Gambar 7. Data evaporasi hasil Isohyet di catchment area AWLR Keru di DAS Babak WS Lombok 


\subsection{Debit air di AWLR Keru}

Data debit yang digunakan adalah data debit pada AWLR Keru rerata 10 tahun dari tahun 2008-2017. Data debit yang digunakan didapat dari data catatan pada stasiun AWLR Keru yang berada di DAS Babak WS Lombok. Berikut ini data debit AWLR rerata 10 tahun di AWLR Keru DAS Babak WS Lombok.

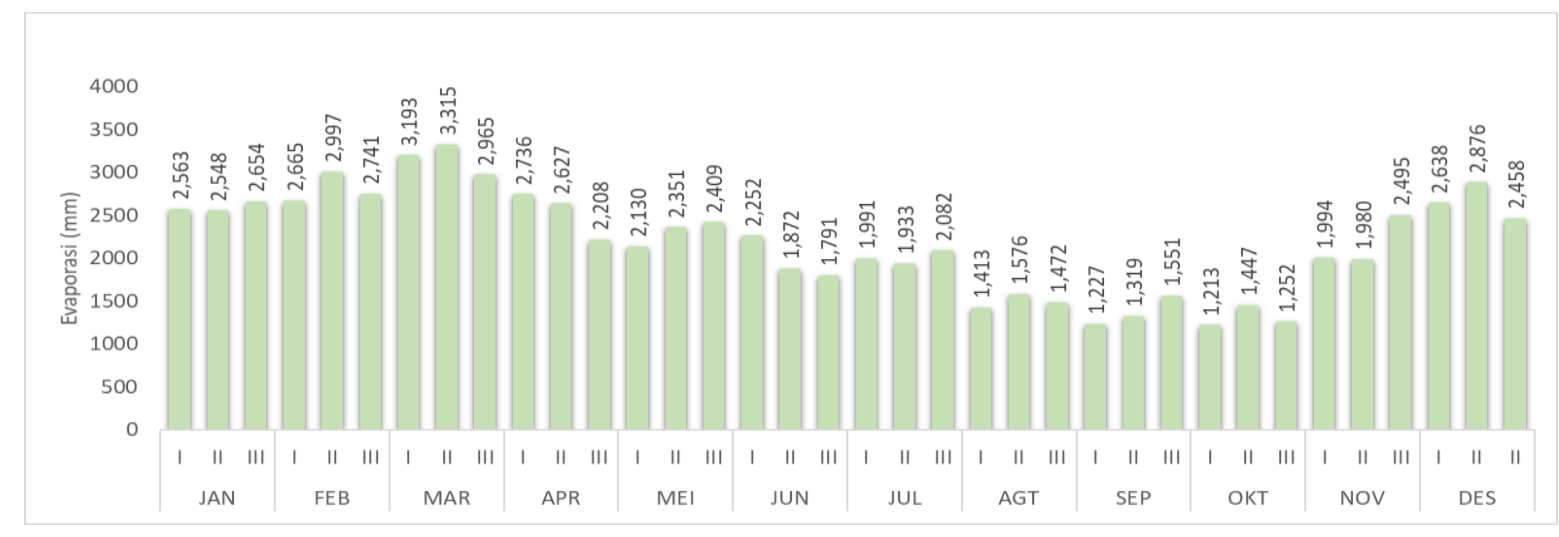

Gambar 8. Data debit AWLR Keru di DAS Babak WS Lombok

\subsection{Kalibrasi model NRECA pada AWLR Keru DAS Babak WS Lombok}

Kalibrasi model rain run NRECA dilakukan pada AWLR keru di DAS Babak dengan inputan data curah hujan, data evapotranspirasi, luas catchment area, serta inputan mata air maupun kebutuhan air irigasi di dalam cacthment area jika ada. Kalibrasi dilakukan menggunakan add in solver yang berada di microsoft excel. Berikut ini hasil dari kalibrasi AWLR Keru di DAS Babak WS Lombok:

a. Koefisien NRECA

- Tampungan kelengasan awal

- Tampungan kelengasan akhir

- Koefisien Reduksi

- Koefisien PSUB

- Koefisien GWF

b. Hasil Kalibrasi

- Beda tampungan awal dan akhir

- Nilai Korelasi

- Nilai volume error (VE)

Berikut ini grafik hasil kalibrasi AWLR Keru di DAS Babak WS Lombok dengan model NRECA, di mana garis biru merupakan hasil pemodelan NRECA dan garis merah merupakan data observasi lapangan melalui stasiun AWLR.

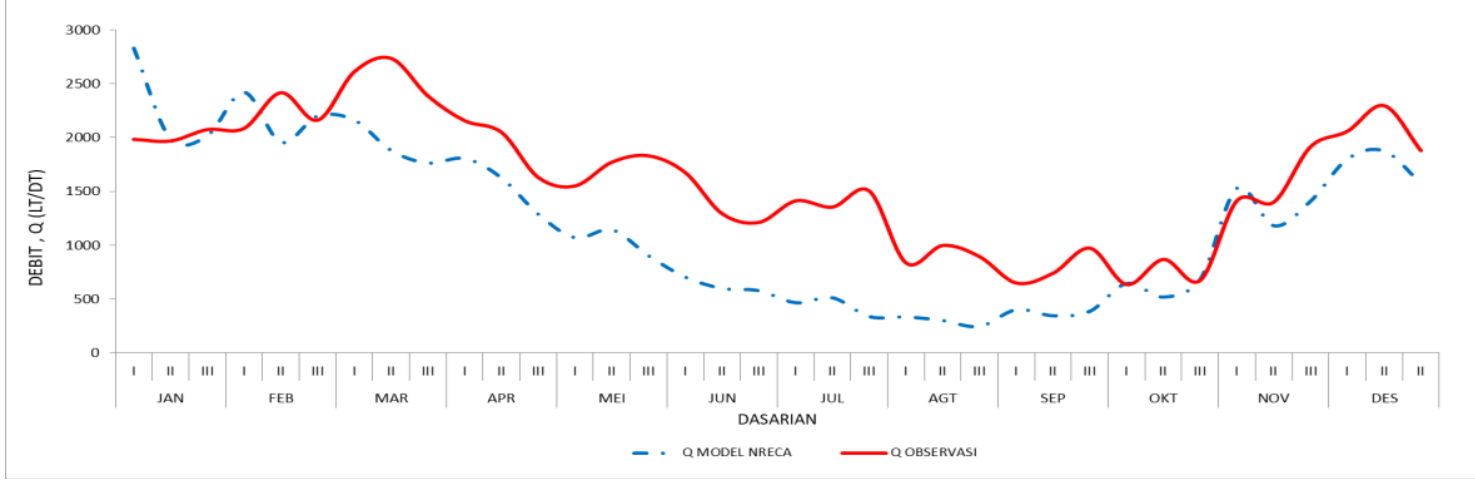

Gambar 9. Grafik hubungan debit model dan observasi hasil kalibrasi NRECA pada AWLR Keru di DAS Babak WS Lombok 


\subsection{Kalibrasi model Tangki pada AWLR Keru DAS Babak WS Lombok}

Kalibrasi model rain run Tangki dilakukan pada AWLR keru di DAS Babak dengan input data curah hujan, data evapotranspirasi, luas catchment area, serta input mata air maupun kebutuhan air irigasi di dalam cacthment area jika ada. Kalibrasi dilakukan menggunakan add in solver yang berada di microsoft excel. Berikut ini hasil dari kalibrasi AWLR Keru di DAS Babak WS Lombok:

a. Koefisien Tangki 1

- Tangki awal : 868

- H $1.1 \quad: 29$

- H $1.2 \quad: 28$

$-\mathrm{F} 1.1 \quad: 794$

- F $1.2 \quad: 661$

- B1 :254

b. Koefisien Tangki 2

- Tangki awal : 330

- B2 :585

c. Hasil Kalibrasi

- Nilai korelasi $\quad: 0.75$

- Nilai volume error (VE) : 0.31

Berikut ini grafik hasil kalibrasi AWLR Keru di DAS Babak WS Lombok dengan model Tangki, di mana garis biru merupakan hasil pemodelan NRECA dan garis merah merupakan data observasi lapangan melalui stasiun AWLR.

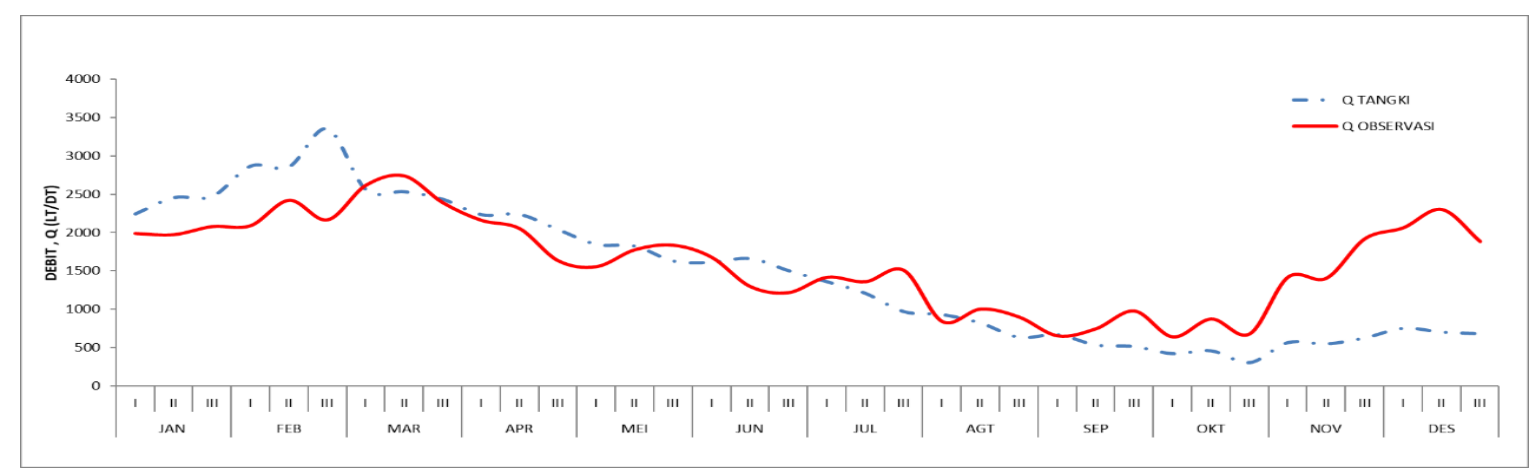

Gambar 10. Grafik hubungan debit model dan observasi hasil kalibrasi model Tangki pada AWLR Keru di DAS Babak WS Lombok

\subsection{Perhitungan Ketersediaan Air}

Perhitungan Ketersediaan air pada Bendung Keru di DAS Babak WS Lombok. Perhitungan debit pemodelan NRECA dan TANK menggunakan data curah hujan pada ARR Keru pada tahun 2018. Berikut data curah Hujan pada ARR Keru:

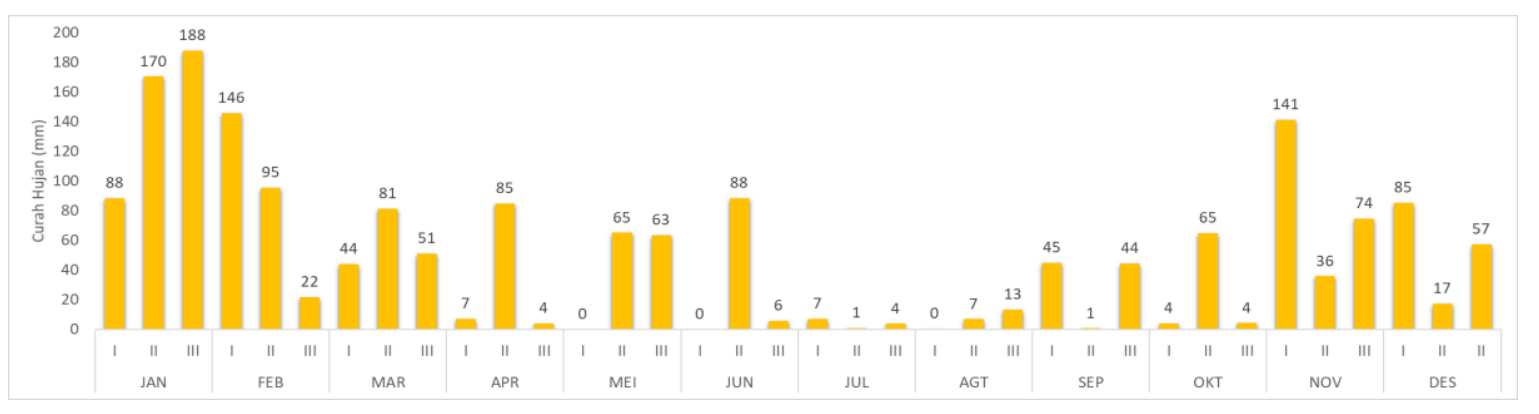

Gambar 11. Data curah hujan pada ARR Keru di DAS Babak WS Lombok 
Perhitungan ketersediaan air menggunakan data curah hujan 2018 hasil pada ARR Keru yang berada di DAS Babak WS Lombok. Debit yang dihitung adalah pada Bendung Keru DAS Babak WS Lombok yang mempunyai luas catchment area sebesar $3.57 \mathrm{~km}^{2}$ serta menggunakan hasil kalibrasi model dari AWLR Keru yang berada di DAS Babak WS Lombok. Berikut tabel perhitungan ketersediaan air berdasarkan hasil analisis dari model NRECA dan Tangki pada tahun 2018.

Tabel 1. Hasil analisis perhitungan model NRECA dan Tangki pada tahun 2018 pada Bendung Keru DAS Babak WS Lombok (Jan-Jun)

\begin{tabular}{|c|c|c|c|c|c|c|c|c|c|c|c|c|c|c|c|c|c|c|c|c|}
\hline \multirow{2}{*}{ No } & \multirow{2}{*}{ Hasil Analisis } & \multirow{2}{*}{ Model } & \multicolumn{3}{|c|}{ Jan } & \multicolumn{3}{|c|}{ Feb } & \multicolumn{3}{|c|}{ Mar } & \multicolumn{3}{|c|}{ Apr } & \multicolumn{3}{|c|}{ Mei } & \multicolumn{3}{|c|}{ Jun } \\
\hline & & & I & II & III & $\mathrm{I}$ & II & III & I & II & III & $\mathrm{I}$ & II & III & I & II & III & I & II & III \\
\hline & Bendung Keru & Observasi & 2687 & 2382 & 2408 & 8310 & 7097 & 2554 & 3237 & 3077 & 3397 & 2891 & 2745 & 2815 & 3390 & 2785 & 3072 & 2884 & 2935 & 2907 \\
\hline & Error Nreca $=0.62$ & NRECA & 2224 & 3611 & 3665 & 3428 & 2576 & 1675 & 1595 & 2164 & 1475 & 871 & 2076 & 784 & 705 & 1599 & 1414 & 627 & 1922 & 594 \\
\hline & R Nreca $=0.302$ & Error Nreca & $17 \%$ & $52 \%$ & $52 \%$ & $59 \%$ & $64 \%$ & $34 \%$ & $51 \%$ & $30 \%$ & $57 \%$ & $70 \%$ & $24 \%$ & $72 \%$ & $79 \%$ & $43 \%$ & $54 \%$ & $78 \%$ & $35 \%$ & $80 \%$ \\
\hline & Error Tanki $=0.52$ & Tanki & 2242 & 2455 & 2471 & 2867 & 2858 & 3353 & 2558 & 2532 & 2434 & 2233 & 2235 & 2039 & 1844 & 1822 & 1627 & 1610 & 1659 & 1502 \\
\hline & $\mathrm{R}$ Tanki $=0.368$ & Error Tanki & $17 \%$ & $3 \%$ & $3 \%$ & $66 \%$ & $60 \%$ & $31 \%$ & $21 \%$ & $18 \%$ & $28 \%$ & $23 \%$ & $19 \%$ & $28 \%$ & $46 \%$ & $35 \%$ & $47 \%$ & $44 \%$ & $43 \%$ & $48 \%$ \\
\hline
\end{tabular}

Tabel 2. Hasil analisis perhitungan model NRECA dan Tangki pada tahun 2018 pada Bendung Keru DAS Babak WS Lombok (Jul-Des)

\begin{tabular}{|c|c|c|c|c|c|c|c|c|c|c|c|c|c|c|c|c|c|c|c|c|}
\hline \multirow{2}{*}{ No } & \multirow{2}{*}{ Hasil Analisis } & \multirow{2}{*}{ Model } & \multicolumn{3}{|c|}{ Jul } & \multicolumn{3}{|c|}{ Agt } & \multicolumn{3}{|c|}{ Sep } & \multicolumn{3}{|c|}{ Okt } & \multicolumn{3}{|c|}{ Nov } & \multicolumn{3}{|c|}{ Des } \\
\hline & & & I & II & III & I & II & III & I & II & III & I & II & III & I & II & III & I & II & III \\
\hline & Error Nreca $=0.62$ & NRECA & 542 & 481 & 394 & 390 & 354 & 341 & 863 & 296 & 825 & 275 & 1148 & 254 & 2434 & 826 & 1468 & 1726 & 637 & 1149 \\
\hline & Error Tanki $=0.52$ & Tanki & 1357 & 1206 & 967 & 928 & 817 & 631 & 666 & 531 & 512 & 418 & 456 & 302 & 563 & 546 & 624 & 750 & 700 & 679 \\
\hline & $\mathrm{R}$ Tanki $=0.368$ & Error Tanki & $54 \%$ & $53 \%$ & $50 \%$ & $58 \%$ & $63 \%$ & $72 \%$ & $70 \%$ & $74 \%$ & $72 \%$ & $79 \%$ & $81 \%$ & $90 \%$ & $75 \%$ & $86 \%$ & $94 \%$ & $76 \%$ & $85 \%$ & $80 \%$ \\
\hline
\end{tabular}

Grafik perbandingan model NRECA dan Tangki terhadap data observasi pada Bendung Keru di DAS Babak WS Lombok, dapat dilihat pada Gambar 12.

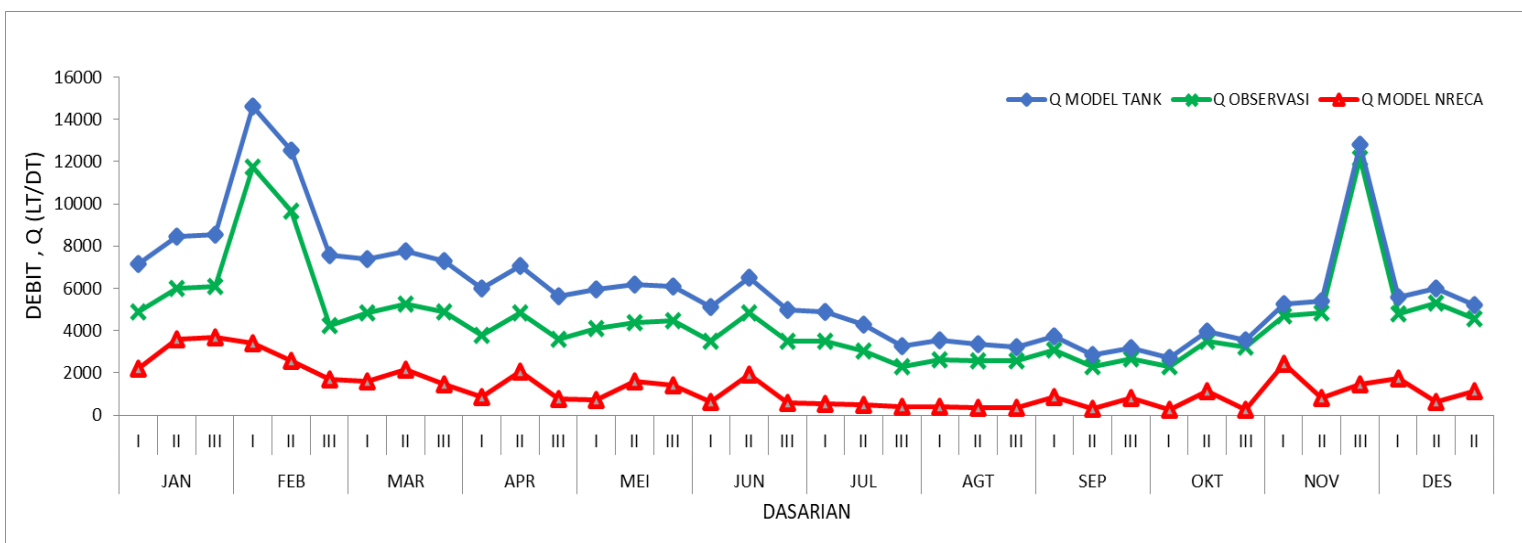

Gambar 12. Grafik hubungan antara debit model NRECA dan Tangki terhadap debit observasi di Bendung Keru DAS Babak WS Lombok.

Berdasarkan hasil pemodelan didapatkan hasil bahwa model Tangki mempunyai nilai lebih baik karena nilai error yang sedikit yaitu $0.52(52 \%)$ sedangkan model Tangki mempunyai nilai error $0.62(62 \%)$. Dan ditunjukkan dengan nilai korelasi model Tangki yang lebih besar yaitu 0.368 sedangkan nilai korelasi NRECA yaitu 0.302. Hal ini menunjukkan bahwa untuk perhitungan ketersediaan air rencana sebagai dasar rencana tata tanam pada Bendung Keru lebih baik menggunakan parameter dan pemodelan Tangki.

\section{Kesimpulan}

Dalam pemodelan debit untuk perhitungan ketersediaan air di DAS Babak WS Lombok terutama pada Bendung Keru menggunakan model Tangki menghasilkan data debit yang cukup baik dibandingkan model NRECA. Pemodelan dilakukan untuk merencanakan pemberian air baik air 
baku, irigasi maupun listrik di tahun rencana kedepan. Pada Pemodelan Bendung Keru didapat hasil yang kurang maksimal hal ini ditunjukan dengan nilai error yang masih tinggi baik model Tangki maupun NRECA. Oleh sebab itu perlu dilakukan kajian lebih lanjut terkait tata guna lahan di dalam cacthment area AWLR yang lakukan kalibrasi maupun ditinjau debit bacaan pada bangunan air dalam hal ini Bendung Keru, sehingga pemodelan mendapatkan hasil yang sesuai dengan data dan kondisi lapangan.

\section{Ucapan terima kasih}

Terima kasih kepada Balai Wilayah Sungai - Nusa Tenggara I yang telah memberikan data yang digunakan sebagai acuan dalam penelitian ini.

\section{Daftar Pustaka}

Akrom, Isnan Fauzan. 2018. "Evaluasi Kinerja Alat Ukur Tinggi Muka Air Otomatis Menggunakan Kalibrator Di Laboratorium." Jurnal Teknik Hidraulik 9(2): 127-38.

Balai Wilayah Sungai - Nusa Tenggara I. 2019. Rencana Alokasi Air Tahunan Wilayah Sungai Lombok Tahun 2019/2020. Mataram: Balai Wilayah Sungai - Nusa Tenggara I.

Dinata, Alharia. 2018. "Optimasi Parameter Model Mock Pada Aliran Sungai Lematang-Lebah Budi." Jurnal Ilmiah Bering 's 05(02): 35-39.

Fachrunnisa, Fauzi Manyuk, and Trimaijon. 2019. "Perbandingan Debit Andalan Hasil Model Tangki Terhadap Debit." Jurnal Teknik 13(2): 177-85.

Fauzi, Manyuk et al. 2019. "Application of Hybrid-Ihacres Models for Water Availability in Siak River." MATEC Web of Conferences 276: 04017.

Hendriyanto, Haris Sofyan, Moh. Yanuar Jarwadi Purwanto, and Yudi Setiawan. 2019. "Penggunaan Model Tangki Untuk Mempelajari Tindakan Konservasi Air Dan Hubungannya Dengan Debit Sungai Di Sub DAS Ciliwung Hulu-Ciliwung Strategy.” Jurnal Keteknikan Pertanian 7(1): 18 .

Julia, Hilda. 2014. "Optimasi Model Hidrologi Mock Daerah Tangkapan Air Waduk Sempor." Jurnal Agrium 18(3): 219-27.

Kementerian Pekerjaan Umum. 2003. "Standar Perencanaan Irigasi.” Kriteria Perencanaan Bagian Jaringan Irigasi KP-01 (1): 6-8.

Kementerian Pekerjaan Umum dan Perumahan Rakyat. 2015. PUPR, JDIH Kementerian Peraturan Menteri Pekerjaan Umum Dan Perumahan Rakyat No. 4 Tahun 2015 Tentang Kriteria Dan Penetapan Wilayah Sungai.

Kesuma, Raras Phusty, Agus Hari Wahyudi, and Suyanto. 2013. "Aplikasi Metode Mock, NRECA, Model Tangki Dan Rainrun Di Bendung Trani, Wonotoro, Sudangan Dan Walikan.” Jurnal Matrik Teknik Sipil 1(4): 472-79.

Noviadi, Satia Cahya, and Ayu Rizki. 2020. "The Influence of Regim's River and Run-off Coefficient in the Catchment Areas of Sidutan and Reak: A Correlation Analysis." IOP Conference Series: Earth and Environmental Science 413(1).

Setiawan, Budi Indra. 2003. “Optimasi Parameter Tank Model.” Jurnal IPB 17(1): 8-16.

Tunas, I Gede, and Surya B Lesmana. 2011. "Analisis Penyimpangan Perkiraan Debit Menggunakan Model Mock Dan NRECA.” Jurnal Infrastruktur 1(1): 54-62. 